\title{
Artikel
}

\section{Het legaat aan een erfgenaam: een gewoon legaat?}

Mr. dr. G.G.B. Boelens*

\section{Algemeen}

In deze bijdrage wordt stilgestaan bij het legaat aan een erfgenaam en de vraag of, en zo ja, in hoeverre, een dergelijk legaat verschilt van een legaat aan een willekeurige derde. ${ }^{1}$ Van oudsher wordt een legaat aan een erfgenaam angeduid als een 'prelegaat'.

In het Romeinse recht bestond naast het 'gewone' prelegaat een bijzondere vorm van een prelegaat: het 'legatum per praeceptionem' (hierna: het voorafnemingslegaat). Het voorafnemingslegaat verschafte de erfgenaam, ten laste van de (mede-)erfgenamen, een zaak die bij de verdeling van de nalatenschap vooraf genomen kon worden. De zaak werd dus bij wijze van verdeling afgegeven en niet door een levering. ${ }^{2} \mathrm{Bij}$ het 'gemone' prelegaat verkreeg de erfgenaam-legataris in het Romeinse recht het gelegateerde goed als legataris voor het deel dat de andere mede-erfgenamen tot het goed gerechtigd waren. Als erfgenaam verkreeg hij verder het deel waartoe hij zelf als erfgenaam gerechtigd was tot het gelegateerde goed. Voor zover het legaat ongeldig was omdat het legaat in het Romeinse recht niet ten laste van de erfgenaam zelf kon komen, kwam hem dit deel dus als erfgenaam toe.

* Mr. dr. G.G.B. Boelens is universitair docent notarieel recht aan de Universiteit Leiden en kandidaat-notaris te Delft.

1. Deze bijdrage is grotendeels ontleend aan hetgeen ik in mijn proefschrift - Het legaat, de wisselwerking tussen civiel en fiscaal recht (diss. Leiden; Ars Notariatus 161), Deventer/Amsterdam: Wolters Kluwer/ Stichting tot Bevordering der Notariële Wetenschap 2015 - heb behandeld in par. 5.6.1 en 5.6.2

2. Zie hierover mijn proefschrift Het legaat, de wisselwerking tussen civiel en fiscaal recht, par. 2.3.5
Uiteindelijk werd het gelegateerde geheel verkregen door de erfgenaam/legataris, zij het dat het deel dat hij niet als legataris verkreeg (iure legati), hij als erfgenaam reeds had verkregen (iure hereditario).

In het navolgende zal worden bezien of, en zo ja, in hoeverre, in het huidige Nederlandse erfrecht een legaat aan een erfgenaam effect sorteert en onder welke titel(s) dan verkregen wordt. Een erfgenaam verkrijgt immers onder algemene titel, terwijl het legaat een opvolging onder bijzondere titel bewerkstelligt. ${ }^{3}$ Krijgt de legataris het andeel waartoe hij als erfgenaam al gerechtigd was als legataris of (in navolging van het Romeinse recht) als erfgenaam? Dit kan namelijk van belang zijn voor de vraag welk deel moet worden ingebracht bij een legaat tegen inbreng van de waarde van het gelegateerde. Kennen wij een onderscheid tussen een 'gewoon' prelegaat en het voorafnemingslegaat? En in hoeverre levert het legaat de erfgenaam-legataris een voordeeltje op? ${ }^{4}$

\section{Het prelegaat als gewoon legaat?}

In deze bijdrage zal ik bepleiten dat het legaat aan een erfgenaam in wezen niet verschilt van een legaat aan een willekeurige derde. De regels over legaten zijn dan ook onverkort op het legaat aan een erfgenaam van toepas-

Zie art. 3:80 lid 2 en 3, 4:182 en 4:117 lid 1 BW

4. Ook rijst de voor de estate-planningspraktijk relevante vraag of een legaat aan de langstlevende echtgenoot (als erfgenaam) effect sorteert als de wettelijke verdeling van toepassing is. Hieraan heb ik in dit tijdschrift aandacht besteed in mijn bijdrage: Het (aanvullend) legaat aan de langstlevende echtgenoot en de wettelijke verdeling, TE 2016, afl. 1, p. 3-9. 
sing en er is naar mijn mening geen behoefte (meer) aan een onderscheid tussen een 'gewoon' legaat en het prelegaat (dan wel het specifieke voorafnemingslegaat).

Het legaat aan een erfgenaam is, gelijk elk ander legaat, een schuld van de nalatenschap (indien het rust op een of meer erfgenamen; art. 4:7 lid 1 sub h van het Burgerlijk Wetboek (BW)). Het legaat komt ten laste van de gezamenlijke erfgenamen, tenzij anders is bepaald door de erflater (art. 4:117 lid 2 BW).

Bovendien, zo volgt expliciet uit de parlementaire geschiedenis, is het krachtens legaat leveren aan een erfgenaam niet aan te merken als een verdeling, maar te beschouwen als de nakoming van een voor rekening van de gemeenschap komende schuld aan een deelgenoot in de zin van artikel 3:182, tweede volzin, BW. ${ }^{5}$

Daarnaast kent ons wetboek - in tegenstelling overigens tot in veel continentale wetten ${ }^{6}$ - geen specifieke regeling voor een legaat aan een erfgenaam en lijkt het dus geen onderscheid te maken tussen de legataris die wel of niet tevens erfgenaam is. Dit laat onverlet dat het enig erfgenaamschap met zich kan brengen dat een verbintenis tot levering van het gelegateerde teniet kan gaan op grond van artikel 6:161 BW.

Om het hiervoor ingenomen standpunt te onderbouwen, behandel ik eerst beknopt enkele arresten over een erfgenaam die tevens legataris (of op andere grond een schuldeiser van de nalatenschap) is.

\subsection{Rechtspraak erfgenaam-schuldeiser}

De Hoge Raad overwoog in het voor de positie van de erfgenaam-legataris belangrijke Schellens-arrest ${ }^{7}$ dat '(...) geen grond bestaat de positie van zulk een legataris anders te beoordelen, indien hij, behalve legataris, ook kind en erfgenaam van den erflater is'. Annotator Beekhuis schrijft onder het arrest in dit verband: 'Het valt nu niet in te zien, waarom de erflater de bevoegdheid zou missen aan een erfgenaam bepaalde zaken te vermaken in dier voege, dat de bepalingen betreffende legaten van toepassing zullen zijn.'

Over het legaat aan een erfgenaam overwoog de Hoge Raad in het hiervoor aangehaalde Schellens-arrest onder meer dat

'(...) het rechtskarakter van een legaat meebrengt dat hij die dit geniet, het gelegateerde goed verkrijgt onder bijzonderen titel;

O. dat het middel berust op de stelling dat, indien, zoals hier, een legaat gemaakt is aan een persoon die tevens behoort tot de erfgenamen van den erflater, deze het gelegateerde goed niet, als andere legataris-

5. NvW, Parl. Gesch. Boek 3, p. 613.

6. Zie voor voorbeelden A.J.H. Pleysier, Het effect van de 'wettelijke verdeling' van de nalatenschap van de eerststervende echtgenoot op een legaat aan de langstlevende echtgenoot in het sinds 1 januari 2003 geldende Nederlandse erfrecht (art. 4:13 BW), in: R. van den Berg \& G. van Niekerk (red.), Libellus ad Thomasium. Essays in Roman law, Roman-Dutch law and legal history in honour of Philip J. Thomas, Pretoria: Unisa Press 2010, p. 306, noot 26.

7. HR 17 januari 1964, NJ 1965/126. sen, onder bijzonderen titel, doch onder algemenen titel verkrijgt;

O. dat als grond voor die stelling onder a wordt aangevoerd dat de verkrijging van de gelegateerde zaak alsdan geschiedt bij scheiding, ten onrechte evenwel, aangezien die zaak, ook indien aan een erfgenaam gelegateerd, niet behoort tot hetgeen tussen de erfgenamen moet worden gescheiden en gedeeld en de legataris de afgifte daarvan uit den onverdeelden boedel kan vorderen; $(. .$.

O. dat, wat tenslotte het onder d gestelde betreft, de omstandigheid dat blijkens 's Hofs beslissing de onderhavige 33 aandelen aan M. Schellens - voor het geheel en niet slechts voor een gedeelte - als legaat werden vermaakt, meebracht dat de desbetreffende testamentaire beschikking haar voor het geheel in de positie van een legataris heeft gesteld en niet slechts voor zodanig gedeelte als waartoe zij tot die aandelen, zonder het legaat, als erfgename niet gerechtigd zou zijn geweest, waaruit volgt dat het legaat als de titel van verkrijging voor het geheel en niet slechts voor zodanig gedeelte van die aandelen behoort te worden aangemerkt;

dat zij mitsdien de haar als legaat vermaakte aandelen voor het geheel onder bijzonderen titel heeft verworven $(\ldots)$ '

De erfgenaam-legataris verkrijgt het gelegateerde goed dus volgens de Hoge Raad voor het geheel als legataris onder bijzondere titel, dus ook het deel dat hij reeds als erfgenaam had.

Zoals opgemerkt is de legataris een schuldeiser van de nalatenschap indien het legaat op een of meer erfgenamen rust (art. 4:7 lid 1 sub h BW). De positie van erfgenaam en tevens schuldeiser van de nalatenschap treft men bijvoorbeeld ook aan als de erflater aan de erfgenaam een goed heeft verkocht en dit goed nog niet voor het overlijden van de erflater is geleverd. Een halfjaar voor het Schellens-arrest had de Hoge Raad reeds uitgemaakt dat voor de erfgenaam-schuldeiser gold dat ' $[\mathrm{h}] \mathrm{et}$ voldoen aan een vordering, die één der erfgenamen op de erflater heeft, levert ook niet op een gedeeltelijke scheiding en deling (...)' ${ }^{8}$ Annotator Beekhuis merkt ook hier op dat '[i]s een goed uit de boedel door de erflater verkocht aan een erfgenaam, dan speelt dit goed voor de boedelscheiding geen rol meer. De situatie is dan niet anders dan wanneer het goed verkocht is aan een derde'.

De beide hiervoor aangehaalde arresten werden bevestigd in de jaren tachtig van de vorige eeuw.

Uit HR 16 april 1982, NJ 1982/580 werd nogmaals duidelijk dat de erfgenaam-legataris het gehele gelegateerde goed onder bijzondere titel verkrijgt en eventuele verplichtingen van de erflater (in casu een door de erflater gesloten overeenkomst met betrekking tot het onroerend goed dat tevens gelegateerd is) dus niet op de legataris overgaan. Overigens laat dat onverlet dat de erfgenaamlegataris als erfgenaam, net als de overige erfgenamen,

8. HR 31 mei 1963, NJ 1964/10. 
wel schadeplichtig kan zijn, naargelang het erfdeel, voor de schade die ontstaan is (vanwege de onmogelijkheid om de overeenkomst nog na te leven door de uitvoering van het legaat). Met andere woorden: de erfgenaamlegataris blijft als erfgenaam verbonden aan de verplichtingen, tenzij de schuldeiser hem ervan ontslaat. ${ }^{9}$

HR 4 maart 1987, NJ 1989/224 bevestigde dat: '[i]ndien, zoals hier, een deelgenoot in een nalatenschap een tot de boedel behorend goed van de erflater heeft gekocht, verkrijgt die deelgenoot door de levering dat goed in zijn geheel ter uitvoering van de koop' (r.o. 4.2). Annotator Kleyn merkt op dat de Hoge Raad in navolging van de advocaat-generaal beslist dat de 'eigendomsoverdracht krachtens koop ook omvat het zich intussen reeds in eigendom bij de koper krachtens erfrecht bevindende onverdeeld aandeel in het thans geleverde goed' ${ }^{10}$ A-G Moltmaker voelde er in zijn conclusie het meest voor om het goederenrechtelijk als volgt te zien: de koper verliest op het moment van de levering krachtens koop zijn eigendom als erfgenaam en krijgt op datzelfde ondeelbare moment zijn eigendom onder bijzondere titel terug. ${ }^{11}$

De positie van de erfgenaam-schuldeiser uit hoofde van legaat of koop van de erflater in de hierboven onder het oude recht gewezen arresten is niet anders dan een schuldeiser die geen erfgenaam is. De gerechtigdheid als erfgenaam met betrekking tot het gelegateerde of verkochte goed blijkt immers geen afbreuk te doen aan de verkrijging van het gehele goed als legataris dan wel als koper.

\subsection{Beoordeling rechtspraak erfgenaam- schuldeiser}

Aangezien de Hoge Raad meermalen overwoog dat het aan een erfgenaam gelegateerde of verkochte niet behoorde tot hetgeen tussen de erfgenamen moet worden gescheiden en gedeeld, en de legataris of koper de afgifte daarvan dan ook uit de onverdeelde boedel kan vorderen, is hiermee duidelijk, in elk geval voor het recht onder het Oud Burgerlijk Wetboek (hierna: OBW), dat het goed aan de erfgenaam-schuldeiser niet bij wijze van verdeling aan de schuldeiser (legataris of koper) toekomt. Voor het Romeinsrechtelijke legaat bij voorafneming, dat mel bij wege van verdeling moest worden afgegeven, ${ }^{12}$ lijkt geen plaats te zijn in de aangehaalde arresten. Ook het Romeinsrechtelijke 'gewone' prelegaat, waarbij gedeeltelijk als legataris en gedeeltelijk als erfgenaam verkregen werd (te weten: de verkrijging als legataris van die delen waartoe de overige erfgenamen gerechtigd zijn tot het gelegateerde, en als erfgenaam van het deel waartoe hij zelf erfgenaam is), vindt men niet in de arresten van de Hoge Raad terug. Sterker nog: de Hoge Raad komt tot een uitkomst van het legaat

9. Zie Asser/Perrick 4 2013/659 en J.Th. Smalbraak, Verkrijging onder algemene en bijzondere titel. NBW 3.4.4.1, NJB 1983, p. 421 en 422 en het naschrift van W.M. Kleyn.

10. Punt 4 annotatie W.M. Kleyn bij HR 4 maart 1987, NJ 1989/224.

11. Concl. onder 3.3. van A-G Moltmaker bij HR 4 maart 1987, NJ 1989/224

12. Zie de instituten van Gaius: Gai. Inst. 2, 217 en 219. aan een erfgenaam, te weten dat het geheel onder bijzondere titel als legataris verkregen wordt (los van de verdeling), die niet denkbaar was in het Romeinse recht. Men kan zich afvragen hoe de Hoge Raad tot die uitkomst kwam. Diverse auteurs, onder wie Pleysier en Van der Ploeg, suggereren dat de Hoge Raad wellicht tot zijn beslissing in de Schellens-zaak is gekomen door de (verkeerde) interpretatie die A-G Van Oosten in zijn conclusie geeft van een uitspraak van Johannes Voet. ${ }^{13}$ $\mathrm{Nu}$ Voet voor het Romeins-Hollands recht uiteenzette dat bij een prelegaat de regel dat 'niemand van zichzelf kan verkrijgen' ('nemo a se ipso capere potest') niet van toepassing is (omdat er niets ten laste van hemzelf komt nu het deel van het gelegateerde dat overeenkomt met het erfdeel in het Romeinse recht als erfgenaam wordt verkregen), ${ }^{14}$ concludeerde Van Oosten uit de uitspraak van Voet over de niet-toepasselijkheid van de 'nemoregel' ten onrechte dat de prelegataris juist wel het gedeelte waarvoor hij erfgenaam is als legataris kan opeisen. ${ }^{15}$ Van Oosten veranderde het Romeinsrechtelijke gewone prelegaat op die manier in een legaat dat geheel als legataris verkregen wordt en daardoor meer qua uitkomst (het verkrijgen van het geheel) leek op een voorafnemingslegaat, zij het dat geen sprake was van toedeling zoals in het Romeinse recht. Zoals eerder aangehaald, nam de Hoge Raad de uitkomst van Van Oosten, de verkrijging door de erfgenaam-legataris van het geheel als legataris, over. ${ }^{16}$

Pleysier merkt over de uitkomst op dat de Hoge Raad hiermee rekening houdt met de bedoeling van de erflater. ${ }^{17}$ Ook in Asser/Perrick wordt opgemerkt dat de Hoge Raad in de Schellens-zaak voor de beslissing cruciale waarde toekent aan de wil van de erflater, nu er wordt overwogen 'dat het voor het geheel is vermaakt en mitsdien het legaat voor het geheel als titel van verkrijging moet worden aangemerkt'. ${ }^{18}$ Als bezwaar van deze uitkomst kan volgens Pleysier worden beschouwd dat hiermee tevens wordt geaccepteerd dat de legataris voor zijn eigen breukdeel zowel schuldenaar-erfgenaam als schuldeiser-legataris is en het vreemd is dat de legataris voor zijn eigen breukdeel aan zichzelf moet leveren. ${ }^{19}$ Dit laatste bezwaar relativeert hij overigens direct zelf door op te merken dat een levering aan zichzelf zich ook

13. Pleysier 2010, p. 307 en P.W. van der Ploeg, Verkrijgen wat men reeds heeft, WPNR 1984/5697, p. 287

14. Voet, Commentarius ad Pandectas, Lib. XXX, XXXI, XXXII, de legatis et fideicommissis, 7: 'Praelegata quod attinet, in iis locum non habet regula superior, quod nemo a se ipso capere possit; ex ratione, quia praelegata heres partim jure hereditario, parte jure legati capit; jure quidem legati pro illis partibus, quibus alii defuncto heredes sunt, jure vero hereditario pro ea parte, qua ipse heres est (...).' ('Wat betreft prelegaten vindt de bovenstaande regel, dat niemand van zichzelf kan verkrijgen, hier geen toepassing. Dit is daarom omdat de erfgenaam deels als erfgenaam deels als legataris verkrijgt. Hij verkrijgt als legataris wat aangaat die delen waartoe de overige erfgenamen gerechtigd zijn, doch als erfgenaam wat aangaat het deel waartoe hij zelf erfgenaam is.') Zie tevens Asser/Perrick 4 2013/659.

15. Concl. A-G Van Oosten bij HR 17 januari 1964, NJ 1965/126.

16. HR 17 januari 1964, NJ 1965/126.

17. Pleysier 2010, p. 308.

18. Asser/Perrick $42013 / 659$

19. Pleysier 2010, p. 308-309. 
bij de verdeling kan voordoen. ${ }^{20}$ Bovendien kan men zich afvragen of de erfgenaam-legataris daadwerkelijk iets verkrijgt wat hij reeds heeft. Inderdaad kan ik niet ontkennen dat de erfgenaam reeds (voor een onverdeeld aandeel) gerechtigd is tot de nalatenschap waarin zich het gelegateerde goed bevindt. Echter, op de erfgenamen (en dus óók op de erfgenaam-legataris zelf wat betreft diens erfdeel) rust een verplichting tot levering van het gelegateerde, een schuld van de nalatenschap. ${ }^{21}$ Deze leveringsverplichting verdwijnt pas na uitvoering daarvan. Na levering van het gelegateerde verkrijgt de legataris dus het gelegateerde goed, zonder dat op hem ten aanzien van dat goed nog een leveringsverplichting rust. In zoverre zou men dus kunnen verdedigen dat de legataris, die tevens erfgenaam is, iets anders heeft verkregen dan hij reeds als erfgenaam had.

Pleysier ziet in de uitkomst van de Hoge Raad, mijns inziens ten onrechte, zoals ik hierna zal uiteenzetten, een legaat bij voorafneming (het Romeinsrechtelijke 'legatum per praeceptionem'), dat vóór alle (ver)deling moet worden afgegeven, maar welke legaatsvorm niet in het oude erfrecht en ook niet in het huidige erfrecht wettelijk is geregeld. ${ }^{22}$ Pleysier vraagt zich (ook voor het huidige recht) af of het arrest van de Hoge Raad tevens ruimte laat voor een ander prelegaat dan dat door een legaat bij voorafneming indien de erflater uitdrukkelijk in het testament zou bepalen dat sprake is van een 'gewoon' legaat. ${ }^{23} \mathrm{Ik}$ vraag mij af of Pleysier hiermee bedoelt dat hij niet uitsluit dat een legaat aan een erfgenaam voor een deel als legataris en voor een deel als erfgenaam kan worden verkregen (het eerder door mij genoemde 'gewone' prelegaat; zie par. 1), temeer daar hij opmerkt dat deze oplossing min of meer zijdelings in het Schellens-arrest is verworpen. ${ }^{24}$ Ik acht deze oplossing, ook voor het huidige recht, echter niet denkbaar, zoals in paragraaf 2.3 zal worden verdedigd.

Hierna zal worden bezien of de door de Hoge Raad in de Schellens-zaak en daarop volgende zaken gevolgde koers, waarbij een legaat aan een erfgenaam voor het geheel door de legataris onder bijzondere titel wordt verkregen, onverkort voor het huidige BW geldt en of de uitkomst in het systeem van het huidige erfrecht past. Is er inderdaad sprake van dat een legaat aan een erfgenaam een legaat bij voorafneming is, zoals Pleysier betoogt? Is met de in het Schellens-arrest naar voren gekomen legaatsvorm, zoals Pleysier opmerkt, inderdaad door de wetgever geen rekening gehouden? ${ }^{25}$ En betekent dit alles dus dat naar Nederlands recht een legaat

20. Pleysier 2010, p. 309 onder verwijzing naar zijn artikel: A.J.H. Pleysier, Moet bij een toedeling de verkrijgende deelgenoot het eigen breukdeel aan zichzelf leveren?, De Notarisklerk 2000/1392, p. 185-186 (hierna: Pleysier 2000a).

21. Vgl. annotatie van Laeijendecker bij HR 4 maart 1987, BNB 1987/149.

22. Pleysier 2010, p. 305-307 en 313 en A.J.H. Pleysier, Het effect van een legaat aan de langstlevende op de wettelijke verdeling, JBN 2011/17, afl. 3, p. 14, par. 6

23. Pleysier 2010, p. 307 en met name noot 33

24. Zie Pleysier 2010, p. 309.

25. Pleysier 2010, p. 305-306 alleen - in de kwalificatie van Pleysier - 'bij wijze van vooruitneming' kan worden gemaakt, of is toch ook een prelegaat denkbaar met een gedeeltelijke verkrijging onder algemene en onder bijzondere titel? Of wordt in de arresten van de Hoge Raad meer gezien dan er eigenlijk is en is er geen sprake van een andere legaatsvorm?

\subsection{Het legaat aan een erfgenaam in het huidige erfrecht}

De vraag kan worden gesteld of met de invoering van het Nieuw Burgerlijk Wetboek (waaronder het erfrecht, zij het pas per 1 januari 2003) de in de zaak Schellens ingezette koers voor de behandeling van het legaat aan een erfgenaam gehandhaafd kan blijven. Het antwoord luidt: ja. Het antwoord kan men vinden in artikel 3:182, tweede volzin, BW en in de parlementaire geschiedenis van dat artikel over de verdeling.

\section{Artikel 3:182 BW luidt:}

\begin{abstract}
'Als een verdeling wordt aangemerkt iedere rechtshandeling waartoe alle deelgenoten, hetzij in persoon, hetzij vertegenwoordigd, medewerken en krachtens welke een of meer van hen een of meer goederen der gemeenschap met uitsluiting van de overige deelgenoten verkrijgen. De handeling is niet een verdeling, indien zij strekt tot nakoming van een voor rekening van de gemeenschap komende schuld aan een of meer deelgenoten, die niet voortspruit uit een rechtshandeling als bedoeld in de vorige zin.'
\end{abstract}

Uit de parlementaire toelichting op de eindtekst van de tweede zin van het hierboven weergegeven artikel blijkt expliciet dat de wetgever wil aansluiten bij de hierboven weergegeven rechtspraak (waaronder het Schellensarrest). Ik citeer de nota van wijziging:

'De ondergetekende wil vooropstellen dat de bepaling van de tweede zin beoogt aan te sluiten bij de huidige rechtspraak, met name bij HR 31 mei 1963, NJ 1964, 10 en 17 januari 1964, NJ 1965, 126. In deze arresten ging het om de voldoening van een vordering uit een door de erflater met twee zijner erfgenamen gesloten koopovereenkomst, respectievelijk van een vordering uit een legaat aan een erfgenaam, derhalve in beide gevallen om de nakoming van een schuld van de nalatenschap aan een of meer erfgenamen. In beide arresten werd aangenomen dat deze nakoming geen verdeling van de nalatenschap opleverde. Buiten twijfel is thans gesteld dat ook de tweede zin van artikel 3.7.1.11 [thans art. 3:182 BW; GB] uitsluitend zodanige gevallen buiten het verdelingsbegrip beoogt te houden.'26

Kortom: hetgeen uit het Schellens-arrest onder het OBW volgde, te weten dat de voldoening van een legaat aan een erfgenaam de nakoming van een schuld van de nalatenschap is en dus geen verdeling opleverde, is voor het nieuwe (huidige) recht gecodificeerd in de tweede

26. NvW, Parl. Gesch. Boek 3, p. 613. 
volzin van artikel 3:182 BW. Het door de erfgenamen leveren van een goed aan een van de erfgenamen krachtens een met de erflater gesloten koopovereenkomst levert dus ook onder het huidige BW geen verdeling op, zoals ook al volgde uit het arrest van HR 31 mei 1963, NJ 1964/10.

Men zou bij het bovenstaande kunnen opmerken dat uit de parlementaire geschiedenis niet met zoveel woorden volgt dat het legaat aan een erfgenaam (altijd) voor het geheel werking heeft als legaat en het dus niet ondenkbaar is dat er enkel voor het deel dat de legataris geen erfgenaam is, inderdaad sprake van de uitvoering van een legaat kan zijn en het overige deel onder algemene titel bij de erfgenaam-legataris terechtkomt. Verdedigd zou dan kunnen worden, zoals Pleysier op grond van de Schellens-zaak niet lijkt uit te sluiten, dat het legaat alleen voor het geheel onder bijzondere titel wordt verkregen als uit het testament niet valt af te leiden dat sprake is van een 'gewoon' prelegaat, bijvoorbeeld omdat het gelegateerde geheel vermaakt is of omdat expliciet in het testament staat dat het legaat vóór de deling moet worden afgegeven. ${ }^{27}$

Hoewel zowel uit de rechtspraak van de Hoge Raad als uit de parlementaire geschiedenis niet expliciet valt op te maken dat een legaat aan een erfgenaam altijd in het geheel onder bijzondere titel verkregen wordt, geven de rechtspraak en de parlementaire geschiedenis ook niet de geringste aanleiding om te concluderen dat een voldoening van een legaat aan een erfgenaam mogelijk is zonder dat het gelegateerde voor het geheel onder bijzondere titel door de erfgenaam-legataris verkregen wordt en dat de voldoening van het legaat aan een erfgenaam anders is als een legaat aan een derde. Sterker nog: de Hoge Raad overwoog in het Schellens-arrest ${ }^{28}$ dat '(...) geen grond bestaat de positie van zulk een legataris anders te beoordelen, indien hij, behalve legataris, ook kind en erfgenaam van den erflater is'. Artikel 3:182 BW laat voorts geen andere uitkomst toe dan dat de uitvoering van een legaat aan een erfgenaam geen verdeling oplevert en dus voor het geheel onder bijzondere titel als legataris verkregen wordt. De vraag kan dan blijven of een legaat uitgevoerd kan worden op zodanige wijze dat de erfgenaam-legataris buiten de verdeling om toch voor een deel het gelegateerde onder algemene titel kan verkrijgen. Dit lijkt mij onmogelijk nu de algemene titel - bij meer erfgenamen - alleen is weggelegd voor de verkrijging krachtens de verdeling (zie ook art. 3:186 lid 2 BW). Hier loopt men dan weer op tegen de laatste

27. Zie Pleysier 2010, p. 307 en met name noot 33, en p. 312. Pleysier stelt zich namelijk de vraag of er voor het huidige recht plaats is voor een 'gewoon' prelegaat indien de erflater uitdrukkelijk in het testament zou bepalen dat sprake is van een 'gewoon' legaat. Zie ook A.J.H. Pleysier, Het legaat aan een erfgenaam in het komend erfrecht (Terug naar Schellens/Schellens), De Notarisklerk 2000/1393, p. 204 (hierna: Pleysier 2000b), waarin Pleysier voor het huidige erfrecht een stilzwijgend legaat bij voorafneming aanneemt, tenzij de erflater met zoveel woorden duidelijk maakt dat het legaat niet bij voorafneming kan worden genomen.

28. HR 17 januari 1964, NJ 1965/126. volzin van artikel 3:182 $\mathrm{BW}$ : de uitvoering van een legaat is geen verdeling en de verdeling is geen uitvoering van een legaat.

Het bovenstaande laat overigens onverlet dat het gelegateerde wel via een overeenkomst tot verdeling (en dus onder algemene titel) bij de erfgenaam-legataris terecht kan komen. In de eerder aangehaalde nota van wijziging bij artikel 3:182 BW wordt geschreven:

'Wel een verdeling is er, wanneer een schuld als hier bedoeld [de schuld uit legaat aan een erfgenaam of de schuld uit verkoop door de erflater aan een erfgenaam; GB) wordt voldaan door inbetalinggeving (artikel 6.1.6.15) [thans art. 6:45 BW; GB) of schuldvernieuwing (bij voorbeeld afstand van de vordering tegen overbedeling van de deelgenoot-schuldeiser). $\mathrm{Er}$ is dan sprake van een nadere overeenkomst tussen de deelgenoten die volgens artikel 3.7.1.11 [thans art. 3:182 BW; GB] een verdeling oplevert. ${ }^{29}$

Pleysier onderschrijft ook de mogelijkheid dat het gelegateerde geheel onder algemene titel via inbetalinggeving' kan worden toegedeeld aan de legataris, waarbij Pleysier opmerkt dat 'de toestemming als bedoeld in art. 6:45 van de schuldeiser, te weten de prelegataris, (...) noodzakelijk voort[vloeit] uit zijn medewerking aan de aldus tot stand gebrachte verdeling der nalatenschap' ${ }^{30}$ Ik ben het tevens met Pleysier eens dat het Schellens-arrest, waar immers werd overwogen dat de gelegateerde zaak ook '(...) indien aan een erfgenaam gelegateerd, niet behoort tot hetgeen tussen de erfgenamen moet worden gescheiden en gedeeld (...)', niet uitsluit, gezien ook de aangehaalde parlementaire toelichting, dat de gelegateerde zaak kan worden toegedeeld aan de erfgenaam-legataris. ${ }^{31}$

Tot slot zij opgemerkt dat ook op grond van de wet de mogelijkheid bestaat dat het aan een erfgenaam gelegateerde goed via verdeling (en dus onder algemene titel) bij de erfgenaam-legataris terechtkomt. Ik doel op de in artikel 4:228 lid 2 BW neergelegde mogelijkheid tussen erfgenamen van toerekening van de schuld uit legaat. Op verlangen van een erfgenaam-legataris wordt de schuld aan deze erfgenaam-legataris uit een - ten tijde van de verdeling opeisbaar - legaat (art. 4:7 lid 1 sub h $\mathrm{BW}$ ) toegerekend op de aandelen van de mede-erfgenamen op wie de schuld uit legaat rusten. Deze toerekening op verlangen van de erfgenaam-legataris resulteert er dan in dat het legaat tenietgaat door het gelegateerde goed in het kader van de verdeling aan de erfgenaamlegataris toe te delen. Het gelegateerde goed wordt dan ook ingevolge deze wettelijke bepaling als erfgenaam krachtens verdeling en niet als legataris verkregen. ${ }^{32}$ Vegter schrijft hierover:

29. NvW, Parl. Gesch. Boek 3, p. 613.

30. Pleysier 2000b, p. 205, noot 20, en p. 202-204.

31. Pleysier 2000b, p. 202-203.

32. J.B. Vegter, Opmerkingen over het legaat aan een erfgenaam mede in het kader van de verdeling van de nalatenschap, WPNR 2015/7047, p. 84 . 
'Het spreekt vanzelf dat als het legaat op deze wijze wordt "afgegeven", van een prelegaat in de door de Hoge Raad bedoelde zin, een legaat dat voor de verdeling uit de boedel wordt voldaan, geen sprake meer is. ${ }^{33}$

\section{Conclusie legaat aan een erfgenaam: een gewoon legaat?}

Mijn conclusie luidt dat een legaat aan een erfgenaam altijd voor het geheel onder bijzondere titel wordt verkregen (behoudens de toepassing van art. 4:228 lid 2 $\mathrm{BW})$, net als elk ander legaat aan een derde. Bij een legaat aan een erfgenaam bestaat alleen nog - in tegenstelling tot een legaat aan een derde - de mogelijkheid dat de erfgenamen (onder wie de erfgenaam-legataris) via de overeenkomst tot verdeling het gelegateerde bij de verdeling aan de erfgenaam-legataris toedelen, zodat deze het gelegateerde in zijn geheel onder algemene titel verkrijgt. Het Nederlandse erfrecht kent dus niet, zo meen ik, in navolging van het Romeinse recht een 'gewoon' prelegaat, waarbij een deel onder bijzondere en een deel onder algemene titel wordt verkregen. ${ }^{34}$

Het onderscheid tussen een legaat, een prelegaat en de bijzondere variant daarvan, zijnde het voorafnemingslegaat, acht ik dan ook verwarrend en niet noodzakelijk. Het legaat aan een erfgenaam wordt, gelijk een legaat aan een derde, of zelfs gelijk met de schuld vanwege een (bijvoorbeeld) door de erflater met een erfgenaam gesloten koop, niet als een verdeling gezien (laatste zin art. 3:182 BW), maar moet als schuld van de nalatenschap (art. 4:7 lid 1 sub h dan wel - voor de schuld uit koop - sub a BW) als een voor rekening van de gemeenschap van een nalatenschap komende schuld door de deelgenoten-erfgenamen worden nagekomen. De constatering van Pleysier dat het legaat aan een erfgenaam 'vóór alle deling' moet worden afgegeven, ${ }^{35}$ heeft voor mij geen extra juridische betekenis dan dat de uitvoering van het legaat geen verdeling is, en in zoverre geen onderdeel van de verdeling is. Uiteraard sluit dat niet uit dat het gelegateerde tot de nalatenschap behoort. Het aan een erfgenaam gelegateerde goed moet op dezelfde wijze 'voor' de verdeling aan de legataris-erfgenaam worden geleverd als dat het gelegateerde goed aan

33. Vegter 2015, p. 84

34. In tegenstelling tot het Romeinse recht, waar veeleer sprake was van een breukdelengemeenschap, lijkt het overdragen van breukdelen bij de verdeling van een specifiek goed van een bijzondere gemeenschap (die de gemeenschap van een nalatenschap is ingevolge art. 3:189 lid 2 BW) niet goed in ons wettelijk systeem te passen (zie ook art. 3:182 en 3:186 BW). Vgl. ook Pleysier 2000b, p. 201-205. Men kan zich immers afvragen of het karakter van de bijzondere gemeenschap meebrengt dat een deelgenoot gerechtigd is tot het geheel (met inachtneming van de rechten van de andere deelgenoten) in plaats van tot een aandeel (breukdeel) van de gemeenschap.

35. Zie o.a. Pleysier 2010, p. 313. de legataris-niet-erfgenaam (of het door de erflater aan een erfgenaam verkochte goed aan een koper-erfgenaam ten titel van koop) 'voor' de verdeling moet worden geleverd. Het valt allemaal onder de laatste zin van artikel 3:182 BW en maakt dus allemaal geen deel uit van de verdeling zelf. Het legaat aan een erfgenaam is dan ook een gewoon legaat.

Tot slot maak ik nog een opmerking: waardetechnisch kan wel worden bereikt dat het legaat als verkrijging voor de gehele waarde boven op het erfdeel van de erfgenaam-legataris komt. Ik doel op de mogelijkheid voor de erflater om in het testament op te nemen dat het legaat aan de erfgenaam ten laste van de erfgenamen-niet-legatarissen komt ingevolge artikel 4:117 lid $2 \mathrm{BW} .{ }^{36}$ Wenst de erflater dat de erfgenaam-legataris ook voor zijn erfdeel in het gelegateerde moet bijdragen en hij voor het overige bevoordeeld wordt, dan laat hij het legaat, zoals de wet ook als hoofdregel formuleert, ten laste van de gezamenlijke erfgenamen komen (art. 4:117 lid 2 BW). Uiteraard is het ook mogelijk dat de erflater de erfgenaam-legataris geen enkel waardevoordeel gunt en een legaat tegen inbreng van de waarde maakt. Nu duidelijk is dat het gelegateerde geheel onder bijzondere titel verkregen wordt, zodat ook deze waarde (de waarde van het

36. Een door de erflater in een testament opgenomen legaat betreft niet een schuld van de erflater die reeds op de dag van het overlijden bestond en die van rechtswege op de erfgenamen overgaat, zoals bedoeld in art. 4:182 BW. Desondanks vormen ook de schulden uit legaten welke op een of meer erfgenamen rusten een schuld van de nalatenschap (art. 4:7 lid 1 sub h BW). Hierbij geldt dat een legaat als hoofdregel op de gezamenlijke erfgenamen komt te rusten, waar bij een deelbare prestatie de belaste erfgenamen ieder voor een deel evenredig aan zijn erfdeel zijn verbonden, tenzij de erflater anders heeft beschikt (art. 4:117 lid 2 en 3 BW). Hoewel art. 4:117 lid 2 BW spreekt over 'ten laste komen van', betreft het hier, afgaande op de parlementaire geschiedenis, niet de draagplicht maar de aansprakelijkheid voor legaten. Vgl. MvA II, Parl. Gesch. Boek 4, p. 742: '(...) Komt het legaat ten laste van een of meer erfgenamen, dan worden zij dus met het overlijden van de erflater schuldenaar van de legataris (...).' Met andere woorden: het gaat hier om de vraag wie de schuldenaren van de legataris zijn geworden. Net als bij schulden van de nalatenschap die niet met de dood van de erflater tenietgaan, wordt er dus wat betreft de aansprakelijkheid voor legaten aangeknoopt bij de erfdelen. Hiervan kan in de uiterste wil zijn afgeweken. Het legaat komt niet op de gezamenlijke erfgenamen te rusten als het legaat door de erflater aan een of meer bepaalde erfgenamen of legatarissen is opgelegd (art. 4:117 lid 2 BW). In dit geval worden dan alleen deze belaste erfgenamen (of legatarissen) schuldenaar, in beginsel dus bij een deelbare prestatie voor een deel evenredig aan het erfdeel (art. 4:117 lid 3 BW). Bij een ondeelbare prestatie, zoals de verplichting om een zaak te leveren, zal sprake zijn van hoofdelijke aansprakelijkheid (art. 6:6 lid 2 BW). Zie ook Parl. Gesch. Boek 6, p. 97. Zoals hierboven vermeld is, ziet art. 4:117 lid 2 BW niet op de draagplicht maar op de aansprakelijkheid, ondanks de verwarrende terminologie 'ten laste van'. Over de (interne) draagplicht regelt de wet niets. Zie W. Breemhaar, De uiterste wilsbeschikking. Beschouwingen over het begrip uiterste wilsbeschikking, de totstandkoming van een uiterste wilsbeschikking als een geldige rechtshandeling en de onderscheiden soorten beschikkingen in het nieuwe Burgerlijk Wetboek (diss. Groningen), Deventer: Kluwer 1992, nr. 166, p. 117 , W.D. Kolkman, Het legaat ten laste van een der erfgenamen, TE 2004, afl. 2, p. 29, W.D. Kolkman, Schulden der nalatenschap (diss. Groningen), Deventer: Kluwer 2006, nr. 3.6.2.1, p. 336 en M.J.A. van Mourik e.a. (red.), Handboek erfrecht, Deventer: Wolters Kluwer 2015, VII.2.4, p. 161. Het is logisch om voor de draagplicht, net als in beginsel bij de draagplicht voor andere schulden van de nalatenschap, aan te sluiten bij de omvang van de erfdelen van de belaste erfgenamen, tenzij uit de uiterste wil anders voortvloeit. Zie Breemhaar 1992, nr. 166, p. 117. 
legaat) in de regel ingebracht moet worden, gaat de legataris er voor de waarde van zijn totale verkrijging (erfdeel en legaat) in vergelijking met de andere erfgenamen niet op vooruit. ${ }^{37}$ Dit kan - mits het erfdeel toereikend is $^{38}$ - overigens ook worden bereikt door het legaat geheel ten laste van de erfgenaam-legataris te maken, zodat alleen de erfgenaam die het legaat krijgt toegekend daarvoor draagplichtig is geworden.

37. Vgl. Pleysier 2000b, p. 201.

38. Gezien de vermindering van het legaat op grond van art. 4:120 BW indien het erfdeel niet toereikend is om de schuld uit legaat te voldoen, waarbij er acht op dient te worden geslagen dat de met het legaat belaste erfgenaam die zuiver aanvaardt ondanks de vermindering van het legaat toch gehouden is de gehele op hem rustende schuld uit legaat te voldoen (art. 4:120 lid 5 en 4:184 lid 2 sub a BW). 